\title{
RESPONSE OF FOUR WHITE CLOVER CULTIVARS TO WINTER APPLIED 2,4-D
}

\author{
P. MARTIN, J.E. WALLER and A. RAHMAN
}

\author{
Ruakura Soil and Plant Research Station, Private Bag, Hamilton
}

The relatively recent introduction of winter active white clover (Trifolium repens) cultivars to the New Zealand pasture scene has raised questions about the winter time application of phenoxy herbicides. Huia white clover sown extensively throughout the country is relatively winter dormant and Maclean (1957) showed that clover damage due to spraying was least during periods of relative dormancy. The newer cultivars Pitau and Kopu have been selected for active winter growth and consequently may be more susceptible to winter spraying.

A pot trial was set up to investigate the effect of a winter 2,4-D application on these newer cultivars and on the standard cultivar, Huia. A European white clover Aran was included in the trial. Aran is a high yielding cultivar, particularly in autumn.

Seed of each cultivar was sown into a Te Kowhai silt loam soil in $0.25 \mathrm{~m}$ x $0.25 \mathrm{~m} \mathrm{x}$ $0.20 \mathrm{~m}$ pots in the glasshouse in November 1985 to produce pure swards. The pots were placed outside 1 month after sowing. One month prior to herbicide application a visual assessment of clover density was made and clover herbage was harvested, dried and weighed. A second visual assessment was made 1 week prior to treatment. In July 1986, the clovers were sprayed with 2,4-D ester (IWD HI ester 2,4-D) at rates of $0,0.5,0.75$, $1.0,1.5$ and $2.0 \mathrm{~kg}$ ai/ha. Spraying was done using a compressed $\mathrm{C}_{2}$ operated tractor mounted boom delivering 300 litres $/ \mathrm{ha}$ at $210 \mathrm{kPa}$. At monthly intervals for 3 months after treatment the clovers were assessed and harvested. Herbage cuts were made to leave a stubble of approximately $2 \mathrm{~cm}$.

Herbage production measured in June, 1 month prior to spraying, showed that Kopu, Pitau and Aran yielded $220 \%, 110 \%$ and $30 \%$ more dry matter (g/pot) than the standard clover, Huia. Visual assessments of sward density prior to treatment showed that Huia, Kopu and Pitau were similar, all having greater sward density than Aran (data not presented).

Initially 2,4-D caused similar percentage losses in clover DM production in all cultivars (Table 1). By September clover was recovering, although the 2,4-D was still having a significant effect (Table 2). At this time yields for all cultivars were similar at all rates of 2,4-D. By the October harvest no herbicide effect could be measured and only cultivar differences were observed (Table 2). Kopu was the highest yielding cultivar in both August and September harvests (Tables 1 and 2). Aran and Huia both grew more vigorously in the spring than in the winter, with Aran yielding significantly better than any other cultivar at the October harvest. Huia never yielded better than Kopu or Pitau at any time during the trial.

TABLE 1: DM yield (g/pot) 1 month after spraying (August).

\begin{tabular}{cccccccrr}
\multirow{2}{*}{$\begin{array}{c}\text { Rate of 2,4-D } \\
\text { (kg ai/ha) }\end{array}$} & \multicolumn{8}{c}{ Clover cultivar } \\
\cline { 2 - 9 } & \multicolumn{2}{c}{ Aran } & \multicolumn{2}{c}{ Huia } & \multicolumn{2}{c}{ Kopu } & \multicolumn{2}{c}{ Pitau } \\
\hline 0 & 3.0 & $(100)^{*}$ & 3.6 & $(100)$ & 14.7 & $(100)$ & 9.5 & $(100)$ \\
0.5 & 1.0 & $(32)$ & 1.5 & $(41)$ & 4.8 & $(32)$ & 3.6 & $(38)$ \\
0.75 & 0.8 & $(27)$ & 0.6 & $(16)$ & 3.1 & $(21)$ & 1.4 & $(14)$ \\
1.0 & 0.5 & $(17)$ & 0.5 & $(14)$ & 2.4 & $(16)$ & 1.2 & $(12)$ \\
1.5 & 0.3 & $(11)$ & 0.5 & $(14)$ & 1.2 & $(9)$ & 1.3 & $(13)$ \\
2.0 & 0.3 & $(9)$ & 0.2 & $(6)$ & 1.1 & $(8)$ & 0.6 & $(6)$ \\
\hline
\end{tabular}

Min. sig. ratio for DM yield $=2.5$.

* Data in brackets are yields as $\%$ of untreated.

Proc. 40th N.Z. Weed and Pest Control Conf. 
TABLE 2: Effect of cultivar and rate of 2,4-D on DM yield (g/pot), 2 and 3 months after spraying.

\begin{tabular}{lrrrrrrr}
\hline \multirow{2}{*}{$\begin{array}{l}\text { Harvest } \\
\text { date }\end{array}$} & Aran & Huia & Kopu & Pitau & & SED \\
\cline { 2 - 6 } & 4.8 & 4.8 & 6.4 & 5.5 & & & 0.4 \\
September & 12.5 & 9.7 & 10.4 & 10.1 & & & 0.8 \\
October & & & $2,4-\mathrm{D}$ & $(\mathrm{kg} \mathrm{ai} / \mathrm{ha})^{2}$ & & & \\
& 0 & 0.5 & 0.75 & 1 & 1.5 & 2.0 & \\
\cline { 2 - 7 } & 8.7 & 7.1 & 5.7 & 4.0 & 3.4 & 3.0 & 0.5 \\
September & 10.4 & 11.1 & 10.6 & 10.1 & 11.3 & 10.3 & 1.0 \\
October & & & & & & & \\
\hline
\end{tabular}

Average yield for all rates used.

${ }^{2}$ Average yield for all cultivars used.

These results suggest there is no difference between the clover cultivars in their response to 2,4-D applied in the winter. Kopu and Pitau were higher yielding over the winter than Aran and Huia, even after spraying. The percentage yield reduction due to $2,4-\mathrm{D}$ was similar for all cultivars. Increasing rates of 2,4 -D did not prolong the period of reduced production as all herbicide effects disappeared between 2 and 3 months after treatment.

\section{REFERENCES}

Maclean, S.M., 1957. Effect of time of spraying on pasture production. Proc. 10th N.Z. Weed Control Conf.: 34-43. 